\title{
The burden of ambiguity : Nicodemus and the social identity of the Johannine Christians
}

\section{Hakola, Raimo}

2009

Hakola , R 2009 , ' The burden of ambiguity : Nicodemus and the social identity of the Johannine Christians ' , New Testament Studies , vol. 55 , no. 4 , pp. 438-455 . https://doi.org/10.1017/S0028688509

http://hdl.handle.net/10138/217493

https://doi.org/10.1017/S0028688509990014

acceptedVersion

Downloaded from Helda, University of Helsinki institutional repository.

This is an electronic reprint of the original article.

This reprint may differ from the original in pagination and typographic detail.

Please cite the original version. 


\title{
The Burden of Ambiguity: Nicodemus and the Social Identity of the Johannine Christians
}

\author{
RAIMO HAKOLA \\ Department of Biblical Studies, P. O. Box 33, 00014 University of Helsinki, Finland \\ email: raimo.hakola@helsinki.fi
}

\begin{abstract}
Nicodemus is an enigmatic literary character who is wavering in no man's land in John's narrative between Jesus' opponents and his true disciples. Some scholars have taken Nicodemus as an example of someone of inadequate faith who remains an outsider throughout the narrative, while others have traced his development from initial and tentative faith to open and public commitment to Jesus. The present article, however, agrees with those who have acknowledged that no single trait determines Nicodemus's portrait, but, in the end, this portrait remains ambiguous. In the article, a text-centered approach to Nicodemus is complemented by asking how this ambiguous literary character may have functioned as a symbol for those who shared John's dualistic tendencies. The article draws upon the social identity approach in order to explain how Nicodemus's ambiguity may have helped the Johannine Christians to accept the uncertainties in their social environment without abandoning the stereotyped and fixed thrust in their symbolic world.
\end{abstract}

Keywords: The Gospel of John, characters in the Bible, Nicodemus, Johannine community, social identity

Nicodemus is an enigmatic character who appears in the NT only three times, all in the Gospel of John (John 3.1-21; 7.45-52; 19.38-42). His character has received a considerable amount of scholarly attention in recent decades. The Johannine narrator does not give much information about the inner life of his different characters, which means that scholars have been compelled to draw conclusions as to the motives of these characters mainly from their external behavior. In the case of Nicodemus, scholars have arrived at very different conclusions concerning his role and function in John's narrative. For some, Nicodemus is an example of someone of inadequate faith who remains an outsider throughout the narrative, while others have traced his development from initial and tentative faith to open and public commitment to Jesus. Still others have acknowledged that no single trait determines Nicodemus's portrait, but, in the end, this portrait remains ambiguous.

In this article, I agree with those who emphasize the ambiguity of Nicodemus's character. I also argue that, while Nicodemus is an ambiguous character in John's 
text world, in the symbolic world that legitimates the social identity of the writer and his audience, even this kind of vague character may support highly dualistic notions evident in the rest of the Gospel. I suggest that some insights from the socalled social identity perspective help us to appreciate a seeming paradox of how such an ambiguous character could have helped John and his audience to hold fast to their fixed symbolic world even when challenged by the mixed and perplexing signals of the real world. ${ }^{1}$

\section{Nicodemus in John and in Recent Studies}

It is noteworthy that scholars rest their conflicting interpretations of Nicodemus on the very same narrative details that they understand in quite opposite ways. In his first appearance, Nicodemus is characterized as a Pharisee and as a leader of the Jews who comes to Jesus by night and confesses that Jesus is a teacher who has come from God (John 3.2). Nicodemus's nocturnal visit, a detail later recalled in the burial scene (19.39), has often been taken symbolically to mean that Nicodemus 'does not walk in light' and 'is not, then, a believer'. Jerome Neyrey does not place much value on Nicodemus's confession in John 3.2 either. For him, it only 'seems like a "confession", but it identifies Jesus with no title of any consequence and it is fraught with ambiguity'. ${ }^{3}$ In this tradition of interpretation, not even Nicodemus's conviction that 'no one can do these signs that you do apart from the presence of God', speaks well for him but reveals that 'Nicodemus is a person for whom the acknowledgment of Jesus' signs is the end as well as the beginning of his acknowledgment of Jesus' . ${ }^{4}$

1 My larger hermeneutical background here is the so-called three-world model developed in a number of writings by Kari Syreeni. See, e.g., K. Syreeni, 'Wonderlands: A Beginner's Guide to Three Worlds', SEA 64 (1999) 33-46; 'Peter as Character and Symbol in the Gospel of Matthew', Characterization in the Gospels: Reconceiving Narrative Criticism (ed. D. Rhoads and K. Syreeni; JSNTSup 184; Sheffield: Sheffield Academic, 1999) 106-52. The model is based on a distinction between a literary work's text world, symbolic world and the real world behind the text. The model can be seen as an attempt to create a holistic context that makes it possible to utilize and combine different methodological approaches that are mostly kept apart in the study of the NT. For the evaluation of the model, see P. Merenlahti, Poetics for the Gospels: Rethinking Narrative Criticism (Studies of the New Testament and its World; London \& New York: T\&T Clark, 2002) 119-24.

2 J. H. Neyrey, 'John III: A Debate over Johannine Epistemology and Christology', NovT 23 (1981) 115-27, esp. 118 n. 11. Nicodemus is also taken as an outsider by R. A. Culpepper, Anatomy of the Fourth Gospel (Philadelphia: Fortress, 1983) 134-6.

3 Neyrey, 'John III', 118-19. Neyrey continues this line of interpretation in his recent commentary; see J. H. Neyrey, The Gospel of John (NCBC; Cambridge: Cambridge University, 2007) 77: 'Nicodemus knows little when he arrives and has learned nothing when he leaves'.

4 R. F. Collins, 'From John to the Beloved Disciple: An Essay on Johannine Characters', Int 49 (1995) 359-69, esp. 363. 
Nicodemus's night-time visit signals for some scholars that he is 'in the darkness of fear and ignorance'. ${ }^{5}$ This is well in line with the understanding of the Gospel as a two-level drama that tells not only of Jesus' life but also of the contemporary situation of the Johannine community. According to this reading, John reflects a bitter and violent conflict between the Johannine group and its opponents in the synagogue, identified as representatives of the post-70 emergent rabbinic Judaism. For the supporters of this paradigm, Nicodemus's nightly visit betrays him as a representative of some believers in the synagogue-even among synagogue leaders (cf. John 12.42) - who did not have the courage to confess their secret faith publicly. ${ }^{6}$

Many scholars are ready to read the opening of Nicodemus's visit to Jesus in a more positive light. Even though the scene takes place at night, it still describes Nicodemus's action as movement to Jesus. ${ }^{7}$ Nicodemus's words to Jesus may be taken to contain 'a key insight that is missing from other [earlier] professions of faith: that Jesus has "come from God",.

Even though the beginning of Nicodemus's encounter with Jesus is open to different interpretations, the sequel of the scene strongly supports those who see Nicodemus in a negative light. In the course of the conversation, Nicodemus takes Jesus' words literally and thus becomes a typical example of Johannine misunderstanding and irony. Jesus' reference to Nicodemus's position as a teacher of Israel (v. 10) increases the irony of the scene by hinting that Nicodemus is not equal to his task. ${ }^{9}$ Jesus makes the gulf between himself and Nicodemus even deeper by saying, 'We speak of what we know and testify to what we have seen; yet you do not receive our testimony. If I have told you about earthly things and you do not believe how can you believe if I tell you about heavenly things?' (vv. 11-12). There has been

5 P. Duke, Irony in the Fourth Gospel (Atlanta: John Knox, 1986) 108.

6 J. L. Martyn, History and Theology in the Fourth Gospel (Louisville: Westminster John Knox, 3rd ed. 2003) 113; D. Rensberger, Overcoming the World: Politics and Community in the Gospel of John (London: SPCK, 1989) 40-1. For criticism of this two-level reading strategy, see below n. 24.

7 Cf. F. J. Moloney, Belief in the Word: Reading John 1-4 (Minneapolis: Fortress, 1994) 108; W. Munro, 'The Pharisee and the Samaritan Woman: Polar or Parallel?', CBQ 57 (1995) 710-28, esp. 716.

8 J. M. Bassler, 'Mixed Signals: Nicodemus in the Fourth Gospel', JBL 108 (1994) 635-46, esp. 637. In a similar vein, R. Schnackenburg, The Gospel According to John (3 vols.; London: Burns \& Oates, 1968-82) 1.370: 'Nicodemus concludes that Jesus must also be a divinely-enlightened teacher. It speaks well for the respected scholar that he seeks out someone who has not been formed in the schools (cf. 7.15), addresses him as "rabbi" and enquires about his doctrine. It is a polite exaggeration when he affirms that the other doctors share his opinion'. Cf. also B. J. Malina and R. L. Rohrbaugh, Social Science Commentary on the Gospel of John (Minneapolis: Fortress, 1998) 81: 'It would be somewhat startling, if not highly improbable, for a member of the Jerusalem elite to address a Galilean villager in this way'.

9 For this irony, see Culpepper, Anatomy, 169; Duke, Irony, 45-6. 
much discussion about what is meant by 'heavenly things' in this connection. As Wayne Meeks has remarked, however, it is not so important to decide this question because 'the point of vs. 12 is not at all the contrast between earthly and heavenly information, but the contrast between the questioner and the one who possesses the information'. ${ }^{10}$

After this, the dialogue turns into Jesus' monologue, and the narrator does not report in any way how Nicodemus responded to Jesus' words. Scholars, however, have been quite willing to fill this gap in the narrative. For those who see Nicodemus as completely ignorant, 'there is no indication in the story that after the extended speech of Jesus in 3.11-21 Nicodemus finally "got it". We do not read about a glimmer of recognition or hesitant attempt to use the Johannine language himself'. ${ }^{11}$ Again, the open ending of the scene leaves room for an opposite reading as well. Winsome Munro notes that the silent Nicodemus stands out from other Pharisees in the Gospel who 'are by no means silent in the face of Jesus' claims but counter them with accusations'. Nicodemus's silence is 'eloquent' and 'denotes, at the very least, attentive and sympathetic listening. ${ }^{12}$

Nicodemus returns to the scene in the meeting of the chief priests and Pharisees, who want to arrest Jesus (7.45-52). In this connection Nicodemus, who is introduced as the one who had gone to Jesus before, and as one of the Pharisees, reminds his colleagues of the principle of their own law: 'Our law does not judge people without first giving them a hearing to find out what they are doing, does it?' Even though Nicodemus here raises his voice for Jesus, the implications of his intervention are quite often neutralized. According to Marinus de Jonge, Nicodemus takes part

10 W. A. Meeks, 'The Man from Heaven in Johannine Sectarianism', JBL 91 (1972) 44-72, esp. 54. Cf. also Malina and Rohrbaugh, The Gospel of John, 84. They remark that 'in antiquity this sort of put-down was directed at those interested in things of the sky yet unable to properly understand life on earth'. They refer to the following parallels: Wis 9.16; 4 Ezra 4.2; Diogenes Laertius 1.34; Ps. Callisthenes Life of Alexander 1.14; Cicero De Republica 1.39 and Seneca Apocolocyntosis 8.3.

11 R. L. Rohrbaugh, 'What's the Matter with Nicodemus? A Social Science Perspective on John 3:1-21', Distant Voices Drawing Near: Essays in Honor of Antoinette Clark Wire (ed. H. E. Hearon; Collegeville, MN: Liturgical, 2004) 145-58, esp. 155. Rohrbaugh interprets John's language as an anti-language that opposes a dominant social order and is incomprehensible to those outside the community where the language is used. Thus also N. R. Petersen, The Gospel of John and the Sociology of Light: Language and Characterization in the Fourth Gospel (Valley Forge, PA: Trinity, 1993) 89-109; Malina and Rohrbaugh, The Gospel of John, 46-8; Neyrey, The Gospel of John, 13-14. While the notion of anti-language works apparently well in the case of Nicodemus in John 3.1-21, it is not clear how it can explain Nicodemus's more promising appearances later in the Gospel.

12 Munro, 'The Pharisee', 725. Cf. also J. Painter, The Quest for the Messiah: The History, Literature and Theology of the Johannine Community (Nashville: Abingdon, 2nd ed. 1993) 198. Painter says that because John does not describe this scene either as a success or as a failure, 'we should see that the quest of Nicodemus progresses through future episodes until final success is narrated, 19.38-42'. 
only in 'an inner-Jewish discussion' where he 'does not take up one of the themes which were developed by Jesus in his own way...[but] only emphasizes the legal requirement that the accused should be granted a proper hearing'. ${ }^{13}$ In this scene, too, Nicodemus remains silent after his fellow Pharisees have mocked him by replying, 'Surely you are not also from Galilee, are you? Search and you will see that no prophet is to arise from Galilee'. Nicodemus's silence is taken as a sign that he acquiesces in this counterclaim. ${ }^{14}$

According to this line of interpretation, Nicodemus's third appearance, in the burial scene, does not fare better for him (19.38-42). Nicodemus brings to the scene 'a mixture of myrrh and aloes, weighing about a hundred pounds'. What is remarkable here is the great quantity of the spices, a detail that has not gone unnoticed by commentators. The abundance of spices is understood as a sign of unbelief because Joseph of Arimathea and Nicodemus regard the burial as final and do not anticipate in any way the following resurrection. ${ }^{15}$ Dennis Sylva has paid special attention to the binding of Jesus' body for burial and takes this detail to show that 'for Nicodemus and Joseph Jesus is held by the power of death; they have not understood Jesus' life beyond death'. ${ }^{16}$

Those who had seen some initial positive signs of Nicodemus's faith already in John 3 have explained the scenes in John 7 and 19 in a fundamentally different way. John Painter says that both Nicodemus's objection to his fellow Pharisees and his participation in Jesus' burial 'chronicle a growing openness and willingness to be identified with Jesus'. ${ }^{17}$ Winsome Munro has noted the important fact that both these actions take place in the public realm which means that, in the end, Nicodemus 'will cast aside his cover and become an open disciple'. ${ }^{18}$ In this case, the large amount of spices in the burial scene may be taken to show that Nicodemus provides Jesus with a royal burial. Raymond Brown says that Joseph and Nicodemus appear as 'men who partially accepted Jesus during his ministry but have been brought by his death to show their love for him'. ${ }^{19}$

13 M. de Jonge, Jesus: Stranger from Heaven and Son of God: Jesus Christ and the Christians in Johannine Perspective (SBLSBS 11; Missoula, MT: Scholars, 1977) 36. Thus also Rensberger, Overcoming, 39; Neyrey, The Gospel of John, 150.

14 Malina and Rohrbaugh, The Gospel of John, 155.

15 de Jonge, Jesus, 34: 'Joseph and Nicodemus are pictured as having come to a dead end; they regard the burial as definitive'. Rensberger, Overcoming, 50 n. 17: 'Nicodemus, like Caesar's Antony but without his irony, has come to bury Jesus, not to raise him'.

16 D. D. Sylva, 'Nicodemus and his Spices', NTS 34 (1988) 148-51, esp. 148.

17 Painter, The Quest, 198.

18 Munro, 'The Pharisee', 716. In a similar vein, J. S. King, 'Nicodemus and the Pharisees', ExpTim 98 (1986) 45; F. J. Moloney, Glory not Dishonor: Reading John 13-21 (Minneapolis: Fortress, 1998) 149.

19 R. E. Brown, The Gospel According to John (2 vols.; AB 29; New York: Doubleday, 1966 and 1970) 2.960. Cf. also Schnackenburg (John, 3.297) who takes Nicodemus's gesture as 'an extraordinary manifestation of respect'. 
Given these highly conflicting views of Nicodemus, it is not surprising that some scholars have claimed that we should not tone down certain obvious tensions in John's presentation. Wayne Meeks already remarked that 'ambiguity is doubtless an important and deliberate part of the portrait of this obscure character'. ${ }^{20}$ Jouette Bassler later pushed this interpretation further and concluded that 'the figure of Nicodemus works powerfully on the reader precisely because it is ambiguous'. Furthermore, 'ambiguity lends a complexity and depth to his figure, which suggests...a more than passing interest on the part of the author of and community behind this Gospel in whomever or whatever Nicodemus represents'. ${ }^{21}$ Colleen Conway has proposed that Nicodemus is not the only ambiguous character in John, but John 'repeatedly portrays characters in indeterminate ways. Again and again, the characters are constructed in ways that pull the reader in multiple directions, frustrating attempts to discern a clearly drawn trait'. ${ }^{22}$

In the following, I agree with those who emphasize the ambiguity of Nicodemus. Those who see Nicodemus only as a representative of unbelief or initial but insufficient faith fail to appreciate some unique features in his portrait. After all, Nicodemus is the only Pharisee in John who is identified as an individual and his role clearly exceeds and differs from the role of those other Jewish leaders-Annas and Caiaphas-who are named in the narrative. ${ }^{23}$ Readings that see Nicodemus totally in a negative light and take him as an outsider are based one-sidedly on John 3 and tone down the force of Nicodemus's comparatively positive gestures in John 7 and 19.

Furthermore, the negative understanding of Nicodemus correlates closely with views that take him as some kind of secret believer who does not have the courage to confess his faith in public and is condemned by John for this reason. This interpretation is yet another recycling of the influential understanding of John's community as persecuted by a powerful Jewish establishment identified as the post-70 rabbinic movement. This earlier consensus has been called severely into question in recent years. ${ }^{24}$ Recent rabbinic studies depict the early

20 Meeks, 'The Man from Heaven', 54.

21 Bassler, 'Mixed Signals', 644. Cf. also J.-M. Sevrin, 'The Nicodemus Enigma: The Characterization and Function of an Ambiguous Actor of the Fourth Gospel', Anti-Judaism and the Fourth Gospel: Papers of the Leuven Colloquium, 2000 (ed. R. Bieringer, D. Pollefeyt and F. Vandecasteele-Vanneuville; Jewish and Christian Heritage Series 1; Assen: Royal van Gorcum, 2001) 357-69, esp. 368-9: 'Nicodemus has not yet found his place in the narrative. He has rightly been said to be ambiguous and marginal, unable to fit in any category... In the end like in the beginning he is the character of a story still to be completed'.

22 C. M. Conway, 'Speaking through Ambiguity: Minor Characters in the Fourth Gospel', Biblint 10 (2002) 324-41, esp. 330.

23 Thus Sevrin, 'The Nicodemus Enigma', 367.

24 Cf. A. Reinhartz, Befriending the Beloved Disciple: A Jewish Reading of the Gospel of John (New York: Continuum, 2001) 37-53; T. Nicklas, Ablösung und Verstrickung: 'Juden' und Jüngergestalten als Charaktere der erzählten Welt des Johannesevangeliums und ihre 
rabbinic movement as a relatively powerless group with little influence on nonrabbinic Jews; so it is not just some minor details in the persecution scenario that are misleading, but the whole model needs to be reconsidered. According to the persecution scenario, Nicodemus is connected to those authorities who feared to confess their faith in Jesus, 'for they loved the glory of men more than the glory of God' (John 12.42). This description, however, is not an unbiased description of some real group in John's surroundings. The charge that someone is a lover of glory was a conventional rhetorical cliché both in Hellenistic polemic and in Jewish and Christian traditions. ${ }^{25}$ The claim that some believing Jews feared to confess their faith may simply be a part of the attempt by the Johannine writer to denigrate those who responded to Jesus in a way he regarded as deplorable.

On the other hand, those who trace the development of Nicodemus's faith simply seem to be reading too much between the lines. Nicodemus's appearances are far too brief and vague to allow us to conclude anything about his inner life. He certainly acts in a relatively positive way as he defends Jesus in front of his fellow Pharisees and honors Jesus by burying him properly. It is too daring, however, in the absence of any clear signs to the contrary, to conclude that he completely left behind his initial misunderstandings and became a full believer. As Jouette Bassler puts it, 'Nicodemus' repeated professions and actions of faith have made him no more than a "proximate other", the other who is beginning to challenge the limits of otherness but who remains "other" nonetheless. For John's community, then, to be in transition, to be of two minds, is still to be outsider' ${ }^{26}$

What makes Nicodemus unique in John is especially the fact that he is clearly a representative of groups-Pharisees and Jews-who are otherwise characterized mainly as Jesus' fierce opponents. ${ }^{27}$ In this sense, he differs even from other

Wirkung auf den impliziten Leser (RST 60; Frankfurt am Main: Peter Lang, 2001) 49-72; R. Hakola, Identity Matters: John, the Jews and Jewishness (NovTSup 118; Leiden: Brill, 2005) 41-6; Raimo Hakola and Adele Reinhartz, 'John's Pharisees', In Quest of the Historical Pharisees (ed. J. Neusner and B. D. Chilton; Waco, TX: Baylor University, 2007) 131-47.

25 For Hellenistic material, see L. T. Johnson, 'The New Testament's Anti-Jewish Slander and the Conventions of Ancient Polemic', JBL 108 (1989) 419-41, esp. 432. For Jewish and Christian material, see Hakola, Identity Matters, 155.

26 Bassler, 'Mixed Signals', 646.

27 For John's characterization of the Jews and the Pharisees, see F. Tolmie, 'The 'IOY $\Delta$ AIOI in the Fourth Gospel: A Narratological Perspective', Theology and Christology in the Fourth Gospel: Essays by the Members of the SNTS Johannine Writings Seminar (ed. G. van Belle, J. G. van der Watt and P. Maritz; BETL 184; Leuven: Leuven University, 2005) 377-97, esp. 395. Tolmie concludes that groups such as the Jews, the Pharisees or the crowd are not really characterized in depth in John because, from John's point of view, it is not important who these groups really are but how they respond to Jesus. In the case of the Pharisees, the most important thing is their almost completely negative response, which explains why 
ambiguous characters in John. ${ }^{28}$ More than in the case of John's other characters, Nicodemus's ambiguity raises questions concerning his place in relation to the dualistic framework of the Gospel. Jean-Marie Sevrin notes that 'the way Nicodemus is characterized makes it impossible to consider "the Jews", who are connected with the Pharisees, to constitute one pole of a dualism'. ${ }^{29}$ According to Colleen Conway, Nicodemus and John's other 'minor characters play a major role in undercutting the dualism of the gospel'. ${ }^{30}$ I fully share this interest in counter-reading John's dualism, but I also want to raise the question as to how successfully Nicodemus's portrait really deconstructs John's two-dimensional view of the world. I agree that, in John's text world, Nicodemus's portrait is different from John's overtly hostile Pharisees and, therefore, as a relatively positive character, he counterbalances the overall negative characterization of the Pharisees and the Jews in the Gospel. I will also try to demonstrate, however, that in the dualistic symbolic world of the Johannine group, even Nicodemus's ambiguity may have supported a highly stereotyped view of the world. I suggest that some insights from the so-called social identity perspective hold much promise for clarifying the role of Nicodemus in relation to the dualistic framework of the Gospel.

'only a small number of traits are revealed' of them. For John's characterization of the Pharisees, see also R. Hakola and A. Reinhartz, 'John's Pharisees', 131-38. Hakola and Reinhartz conclude that, while the Pharisees are not the only Jews that are blamed for Jesus' death in John's narrative world, they are the ones portrayed as seeking his destruction from the outset. They also note that Nicodemus is not typical of the Johannine Pharisees; only he stands out though even he does not openly express his convictions.

There have been attempts at defining the meaning of the term 'Iov $\delta$ ĩot in John as referring only to some particular Jewish group, be it Judeans or the Jewish authorities, but these attempts are not totally satisfying. For discussion, see Hakola, Identity Matters, 10-16 and 225-31. The indiscriminate use of the term shows that, even in those instances where 'the Jews' could be understood as a specific group of Jewish leaders or Judaeans, the conflict between these groups and Jesus is raised to a new and more general level. Cf. R. A. Culpepper, 'The Gospel of John as a Document of Faith in a Pluralistic Culture', 'What is John?': Readers and Readings of the Fourth Gospel (ed. F. F. Segovia; SBLSymS 3; Atlanta: Scholars, 1996) 107-27, esp. 114; A. Reinhartz, “Jews” and Jews in the Fourth Gospel', AntiJudaism and the Fourth Gospel (ed. Bieringer, Pollefeyt and Vandecasteele-Vanneuville) 341-56, esp. 348.

28 Conway ('Speaking', 331-9) identifies as ambiguous characters in John-in addition to Nicodemus-Peter, Pilate, the Samaritan woman, Martha and Mary of Bethany, Mary Magdalene, the mother of Jesus and the beloved disciple.

29 Sevrin, 'The Nicodemus Enigma', 369.

30 Conway, 'Speaking', 325. 


\section{The Social Identity Approach}

Social identity theory was first developed by social psychologist Henri Tajfel and his colleagues in Great Britain in the late 1960 s and early 1970 . $^{31}$ This approach has increasingly been applied to early Jewish and Christian sources. $^{32}$ One of the key ideas behind the theory was formulated by Tajfel as the 'minimal group paradigm'. ${ }^{33}$ In a series of experiments Tajfel and his colleagues found that, even in minimal groups where there is neither conflict of interest nor previously existing hostility, people tend to favor ingroup members over outgroup members. This means that 'the mere perception of belonging to two distinct groups-that is, social categorization per se-is sufficient to trigger intergroup discrimination favoring the in-group'. ${ }^{34}$ The need for social differentiation between groups 'is fulfilled through the creation of intergroup differences when such differences do not in fact exist, or the

31 For general introductions to the theory, see M. A. Hogg and D. Abrams, Social Identifications: A Social Psychology of Intergroup Relations and Group Processes (London and New York: Routledge, 1988) 6-29; J. C. Turner, 'Some Current Issues in Research on Social Identity and Self-Categorization Theories', Social Identity: Context, Commitment, Content (ed. N. Ellemers, R. Spears and B. Doosje; Oxford: Blackwell, 1999) 6-34; R. Brown, 'Social Identity Theory: Past Achievements, Current Problems and Future Challenges', European Journal of Social Psychology 30 (2000) 745-78; S. A. Haslam, Psychology in Organizations: The Social Identity Approach (London: Sage, 2001) 26-57.

32 P. F. Esler, Galatians (London and New York: Routledge, 1998) 40-57; Conflict and Identity in Romans: The Social Setting of Paul's Letter (Minneapolis: Fortress, 2003) 19-39. Two recent collections contain several articles introducing and applying the social identity approach. See P. Luomanen, 'The Sociology of Knowledge, the Social Identity Approach and the Cognitive Science of Religion', Explaining Early Judaism and Christianity: Contributions From Cognitive and Social Science (ed. P. Luomanen, I. Pyysiäinen and R. Uro; BibInt Series 89. Leiden: Brill, 2007) 199-229; R. Hakola, 'Social Identities and Group Phenomena in the Second Temple Period', Explaining Early Judaism and Christianity (ed. Luomanen, Pyysiäinen and Uro) 259-76; J. Jokiranta, 'Social Identity in the Qumran Movement: The Case of the Penal Code', Explaining Early Judaism and Christianity, 277-98; T. Kazen, 'Son of Man and Early Christian Identity Formation', Identity Formation in the New Testament (ed. B. Holmberg and M. Winninge; WUNT 227; Tübingen: Mohr-Siebeck, 2008) 97-122; R. Hakola, 'Social Identity and a Stereotype in the Making: The Pharisees as Hypocrites in Matt 23', Identity Formation (ed. B. Holmberg and M. Winninge) 123-39; R. Roitto, 'Act as a Christ-Believer, as a Household Member or as Both? A Cognitive Perspective on the Relationship between the Social Identity in Christ and Household Identities in Pauline and Deutero-Pauline Texts', Identity Formation (ed. Holmberg and Winninge) 141-61.

33 For minimal groups, see H. Tajfel, Human Groups and Social Categories: Studies in Social Psychology (Cambridge: Cambridge University, 1981) 33-238 and 268-76; H. Tajfel and J. C. Turner, 'An Integrative Theory of Intergroup Conflict', The Social Psychology of Intergroup Relations (ed. W. G. Austin and S. Worchel; Monterey, California: Brooks/Cole, 1979) 33-47, esp. 38-40.

34 Tajfel and Turner, 'Integrative Theory', 38. 
attribution of value to, and the enhancement of, whatever differences that do exist'. ${ }^{35}$

The findings connected to minimal group studies resulted in the formulation of the concept of social identity, which can be understood as 'that part of an individual's self-concept which derives from his [sic] knowledge of his membership of a social group (or groups) together with the value and emotional significance attached to that membership'. ${ }^{36}$ The concept of social identity was later developed into a more general explanation of all cognitive processes connected to group formation in the so-called Self-Categorization Theory. According to John Turner and other social psychologists, 'the central hypothesis for group behaviour is that, as shared social identity becomes salient, individual self-perception tends to become depersonalized'. ${ }^{37}$ This means that when we experience ourselves as identical with a certain class of people and in contrast to some other classes, we tend to stereotype not only the members of outgroups, but also ourselves as a member of our own ingroup. Therefore, the process of categorization concerns both the self-conception of an individual in relation to his or her ingroup and people who are experienced as different from the ingroup. Social categorization helps individual group members to orientate themselves in variable social environments by making those environments more predictable and meaningful. Self-categorization theory emphasizes that categorization is always a dynamic, contextbound process, which results in maximizing the clarity of intergroup boundaries in a given social context. Social categories are not inflexible but always dependent on the specific social environment and those comparative relations that are present in that environment. It can even be claimed that 'people who are categorized and perceived as different in one context...can be recategorized and perceived as similar in another context'. ${ }^{38}$

One of the basic observations of the social identity approach is that human social behavior varies along the 'interpersonal and intergroup continuum'. ${ }^{39}$ At the interpersonal extreme, social encounters are determined by personal relationships between human beings while at the intergroup extreme, membership in different social groups determines human behavior. This continuum explains how, under certain conditions, social identity may become more salient than personal identity for the behavior of individuals.

There are good reasons to think that, like other early Christian writings, the Gospel of John betrays traces of intergroup behavior and reflects attempts to construct and solidify a distinct social identity of a group of Jesus' early followers.

35 Tajfel, Human Groups, 276.

36 Tajfel, Human Groups, 255.

37 Turner, 'Some Current Issues', 12.

38 P. J. Oakes, S. A. Haslam and J. C. Turner, Stereotyping and Social Reality (Oxford: Blackwell, 1994) 98.

39 Cf. Tajfel, Human Groups, 228-53. 
First, many cultural anthropologists have made a distinction between individualistic and collectivistic cultures. This distinction may not be so definite as has sometimes been postulated, but it is difficult to deny that, in Mediterranean antiquity, people were commonly seen as deeply embedded in different groups that were essential for their identity. ${ }^{40}$ Second, many studies on the Dead Sea Scrolls or early Christian writings, especially the Gospels, have emphasized communal aspects in these writings; while written by different individuals, these writings give voice to different groups by expressing their collective convictions and shared view of the world. To be sure, this view has recently been challenged. ${ }^{41}$ This recent criticism may be justified in the sense that many earlier redaction critical studies have gone quite far in their detailed reconstructions of various histories of Christian communities. ${ }^{42}$ It is also undeniable that the canonical Gospels contain several features that appealed to a wide range of different Christian communities beyond their local area of origin. However, both the evidence of the reception of the Gospels in the early church and various extra-canonical texts suggest that it is not anachronistic to think that the Gospels mirror, at least to some extent, the experiences and needs of those particular communities where they were produced. ${ }^{43}$ It is thus productive to ask how Nicodemus's literary character may have supported the social identity of the Johannine author and his audience.

\section{Social Identity and Nicodemus}

In the following, I try to show what possibilities the social identity perspective holds for explaining John's portrait of Nicodemus. I think that this perspective helps to understand both Jesus' harsh words to Nicodemus in John 3 and Nicodemus's more positive appearances later in the narrative.

40 Cf. Esler, Galatians, 45-49.

41 Most notably, see R. Bauckham, 'For Whom Were Gospels Written?', The Gospels for All Christians: Rethinking the Gospel Audiences (ed. R. Bauckham; Grand Rapids: Eerdmans, 1998) 9-48. For a reconsideration of whether it is possible to trace the history of a specific Johannine community, see R. Kysar, 'The Whence and Whither of the Johannine Community', Life in Abundance: Studies of John's Gospel in Tribute to Raymond E. Brown (ed. J. R. Donahue; Collegeville, MN: Liturgical, 2005) 65-81.

42 For methodological criticism of J. L. Martyn's two level reading of John, see Hakola, Identity Matters, 18-22.

43 See especially, M. M. Mitchell, 'Patristic Counter-Evidence to the Claim That "The Gospels Were Written for All Christians"', NTS 51 (2005) 36-79; T. Kazen, 'Sectarian Gospels for Some Christians? Intention and Mirror-Reading in the Light of Extra-Canonical Texts', NTS 51 (2005) 561-78. For earlier criticisms of Bauckham's views, see P. F. Esler, 'Community and Gospel in Early Christianity: A Response to Richard Bauckham's Gospels for All Christians', SJT 51 (1998) 235-48; D. C. Sim, 'The Gospels for All Christians. A Response to Richard Bauckham', JSNT 84 (2001) 3-27. 
What is remarkable in Nicodemus's first appearance is Jesus' cruel response to him. Nicodemus does not seem to have come to Jesus with hostile or suspicious intentions. However, the Johaninne Jesus has no time to wait on what Nicodemus has in his heart but starts to pinpoint what is wrong with Nicodemus. Wayne Meeks has remarked that 'the unbiased reader feels quite sympathetic with poor Nicodemus and the "believing" Jews with whom, it seems, Jesus is playing some kind of language-game whose rules neither they nor we could possibly know'. ${ }^{44}$

Why does Jesus respond so harshly to the sincere quest of Nicodemus? Scholars have usually answered this question by referring to some of Nicodemus's individual characteristics that betray his shortcomings. As we have seen, his night-time visit is said to speak to his fear and willingness to hide his faith. Or, it is claimed that his confession is based only superficially on Jesus' signs. Several times Nicodemus is compared to other characters-the disciples, the Samaritan woman or the man born blind in John 9-and these comparisons are very much to Nicodemus's disadvantage. It is not so easy, however, to differentiate between Nicodemus and other characters of the story. For example, the faith of the disciples is based on Jesus' sign at the wedding in Cana (John 2.11), and 'the careful reader is left wondering just what distinguishes Nicodemus's sign-based faith from that of the disciples' ${ }^{45}$ Likewise, the Samaritan woman acknowledges Jesus as a prophet after Jesus has miraculously explained her marital past (4.19). The blind man in John 9 repeatedly comes back to Jesus' miracle in his confessions of who Jesus is and he is like Nicodemus-not unlike, as is often argued-in defending Jesus in the face of wrong accusations by the Pharisees. ${ }^{46}$ In John 19.38, Joseph of Arimathea-and perhaps also by implication Nicodemus-is said to be Jesus' secret disciple 'because of his fear of the Jews', which corresponds with the remark that, after Jesus' resurrection, his disciples met behind closed doors for fear of the Jews (20.19). These comparisons fail to locate a single and definitive reason for Jesus' surprisingly harsh and uncompromising censure of Nicodemus in John 3. According to Jesus' rebuke, Nicodemus is not going halfway from initial and insufficient faith towards the confession of his faith; Jesus categorically denies any positive faith on the part of Nicodemus and makes him and his group the complete opposite to Jesus and his followers.

Richard Rohrbaugh is on the right track when he disapproves of attempts to attribute 'one failing or another to Nicodemus' as an explanation for what is the

44 Meeks, 'The Man from Heaven', 68. Bassler ('Mixed Signals', 637 and 638) speaks of Jesus' 'surprisingly acerbic response' to Nicodemus and adds that Jesus treats Nicodemus 'rather shabbily'.

45 Bassler, 'Mixed Signals', 637-8.

46 Nicodemus and the blind man are compared—-to Nicodemus's disadvantage—by Rensberger, Overcoming, 37-49. 
matter with him. According to Rohrbaugh, 'Nicodemus' experience with Jesus was exactly that of any outsider, whether an inquirer or not, who encountered a Johannine type for the first time'. ${ }^{47}$ While Rohrbaugh connects Jesus' response to the notion of John's language as an anti-language, I think that some much more general features of intergroup relations help to clarify the scene.

The key to understanding Jesus' rude response is to realize that Jesus does not confront Nicodemus here as an individual with recognizable characteristics that distinguish him from other individuals. Rather, Jesus takes him as a member and representative of groups-Pharisees and Jews-who are presented as symbols of unbelief and as Jesus' opponents throughout the Gospel. In social identity terms, we have here an example of intergroup behavior. According to the social identity approach, interpersonal behavior becomes intergroup behavior when individuals are not judged according to their own individual characteristics but are seen as depersonalized representatives of the groups to which they belong. In situations of this kind, members of the ingroup tend to 'treat members of the outgroup as undifferentiated items in a unified category, i.e. independently of the individual differences between them'. Furthermore, ingroup members attribute to outgoup members 'traits assumed to be common to the groups as a whole'. ${ }^{48}$ In Nicodemus's first meeting with Jesus, it is the essence of the groups to whom he belongs that dictates Jesus' response to him, not some individual characteristics of this particular teacher of Israel.

In social identity terms, Nicodemus's more positive appearances are not necessarily in contradiction to his first meeting with Jesus. The social identity theory was originally developed to explain intergroup discrimination and it addressed such questions as 'Why do people in groups discriminate against each other?' From this perspective, a simple answer would be that, because of social categorization, people commonly tend to favor ingroup members and discriminate against outgroup members. Some recent studies, however, have revealed that it is problematic to think that ingroup members are universally regarded as more attractive than outgroup members. In particular, José Marques and his colleagues have tried to explain the function of deviant group members for social identity. ${ }^{49}$ In a series of experiments, they found evidence

47 Rohrbaugh, 'What's the Matter?', 151.

48 Tajfel, Human Groups, 243.

49 J. M. Marques, V. Y. Yzerbryt and J.-P. Leyens, 'The "Black-Sheep Effect": Extremity of Judgments towards Ingroup Members as a Function of Group Identification', European Journal of Social Psychology 18 (1988) 1-16; J. M. Marques and V. Y. Yzerbryt, 'The BlackSheep Effect: Judgmental Extremity towards Ingroup Members in Inter- and Intra-Group Situations', European Journal of Social Psychology 18 (1988) 287-92; J. M. Marques, 'The "Black-Sheep Effect": Outgroup Homogeneity in Social Comparison Settings', Social Identity Theory: Constructive and Critical Advances (ed. D. Abrams and M. A. Hogg; London: Harvester Wheatsheaf, 1990) 131-51; J. M. Marques, E. M. Robalo and S. A. Rocha, 'Ingroup 
for what they called the 'black sheep effect'. This term conceptualizes a commonsense observation that a person who behaves against the norms of an ingroup is even more strongly rejected than the members of outgroups. The 'Black sheep effect' means that ingroup members are judged more extremely than outgroup members who have similar attitudes and values. An interesting observation made in the research on the 'black sheep effect' is that an outgroup member who behaves against the norms of the outgroup in a way that is in line with ingroup norms is quite often evaluated more positively than an ingroup member who acts against the ingroup norms. This phenomenon has nothing to do with the personal qualities of the members in question but is dependent on the significance of the ingroup norms for social identity. The relative approval of the 'friendly' outgroup members is explained by the fact that, from the perspective of an ingroup, outgroup deviants help to undermine the legitimacy of the outgroup and, at the same time, help to verify the social reality implied by the ingroup norms. ${ }^{50}$

As a Pharisee who speaks for Jesus, Nicodemus perfectly fits the role of a deviant outgroup member who supports the ingroup norms. ${ }^{51}$ According to the above-mentioned studies, people are quite capable of making distinctions between likable and unlikable ingroup members, or between likable and unlikable outgroup members without diminishing the significance of the boundaries between the respective in- and outgroups. In the case of Nicodemus this means that, even though his action in the meeting of the Pharisees has a positive value for the Johannine community, he is not necessarily presented as becoming a believer. Especially as an outsider, Nicodemus undermines the claims of Jesus' Pharisaic opponents by showing that their own law does not unequivocally support Jesus' guilt. This theme continues in John 11.47-53 where, after a political

Bias and the "Black Sheep" Effect: Assessing the Impact of Social Identification and Perceived Variability on Group Judgments', European Journal of Social Psychology 22 (1992) 331-52; J. M. Marques, 'The Role of Categorization and In-Group Norms in Judgments of Groups and Their Members', Journal of Personality and Social Psychology 75 (1998) 976-88; J. M. Marques, 'Social Categorization, Social Identification, and Rejection of Deviant Group Members', Blackwell Handbook of Social Psychology: Group Processes (ed. M. A. Hogg and R. S. Tindale; Oxford: Blackwell, 2001) 400-24.

50 Marques et al., 'The Role of Categorization', 986-7; D. Abrams , 'Pro-Norm and Anti-Norm Deviance Within and Between Groups', Journal of Personality and Social Psychology 78 (2000) 906-12, esp. 911; Marques et al., 'Social Categorization', 418.

51 For a similar kind of conclusion with regard to Gamaliel (Acts 5.21-42) and other relatively friendly Pharisees (Acts 23.1-10) in Luke-Acts, see Raimo Hakola, "Friendly" Pharisees and Social Identity in the Book of Acts', Contemporary Studies in Acts (ed. T. E. Phillips; Macon, GA: Mercer University, 2009) 181-200. 
intrigue and without a legitimate reason, the Pharisees and the chief priests finally reach the decision to kill Jesus. ${ }^{52}$

A social identity perspective also helps to explain what kind of function Nicodemus's ambiguity may have had for the maintenance of the distinct social identity of the Johannine writer and his audience. Nicodemus brings a certain amount of uncertainty into a narrative that is otherwise characterized by the clear distinction between light and darkness, faith and unbelief. According to John's dualistic notions, believers and unbelievers (the latter represented especially by the Jews in John's narrative) are clearly distinct from each other. We have every reason to suppose, however, that the social reality behind the Gospel was far more diverse and complex.

The scenario that sees John's community as a persecuted Jewish minority is based on the assumption that Jewish synagogue communities had strict boundaries that were defined by a strong leadership class. But there is evidence that Jewish synagogue communities were not so clearly defined but open to their surroundings in many different ways. For example, Shaye Cohen has shown that even the Gentiles could interact with Jewish communities in a variety of waysfrom admiring some aspects of the faith of the Jews to full conversion. ${ }^{53}$ The evidence for different types of 'sympathizers' and full converts shows that the boundary between Jews and Gentiles was crossable. ${ }^{54}$ It is fully possible that the boundary between the Jews who came to believe in Jesus and other Jews also still remained open and fluid at the end of the first century. Because there was not one ruling class among the Jews even after the destruction of the temple, the Jews' responses to Jesus' followers were not backed by any authorities and it may be that these responses were not so completely negative as is suggested by early Christian polemics against the Jews. ${ }^{55}$

52 The portrayal of Jesus as an innocent victim at the hands of the Jewish rulers can be taken as an attempt to validate the social identity of the Johannine Christians who had abandoned basic markers of Jewish identity and marginalized themselves in relation to other Jews. See Raimo Hakola, 'The Counsel of Caiaphas and the Social Identity of the Johannine Christians (John 11:47-53)', Lux Humana, Lux Aeterna: Essays on Biblical and Related Themes in Honour of Lars Aejmelaeus (ed. A. Mustakallio in collaboration with H. Leppä and H. Räisänen; Publications of the Finnish Exegetical Society 89; Helsinki/Göttingen: Finnish Exegetical Society/Vandenhoeck \& Ruprecht, 2005) 140-63.

53 S. J. D. Cohen, The Beginnings of Jewishness: Boundaries, Varieties, Uncertainties (Berkeley, Los Angeles, London: University of California, 1999) 140-74.

54 Cohen, The Beginnings, 54. Cf. also T. Rajak, The Jewish Dialogue with Greece and Rome: Studies in Cultural and Social Interaction (AGJU 48; Leiden: Brill, 2001) 346-8. Rajak emphasizes the 'activity on the boundaries' which speaks for the openness of Jewish Diaspora communities.

55 Cf. C. Setzer, Jewish Responses to Early Christians: History and Polemics, 30-15o C.E. (Minneapolis: Fortress, 1994) 167-8. Setzer remarks that in early Christian sources Jews are every now and then presented as fair-minded and tolerant, even though the negative 
Jews who came to believe in Jesus may have dealt with synagogue communities and their members in different ways. Some who believed in Jesus may have become alienated from their fellow Jews to the extent that they felt themselves expelled from the synagogue (John 9.22). Some other believers may have continued to interact with other Jews and found the practice of basic matters of Jewishness still attractive. It may be that we have an allusion to such Jews in John 8.30-31 where the Johannine narrator says that many Jews believed in Jesus. ${ }^{56}$ In the course of the subsequent dialogue in 8.31-59, John connects even these believers with the devil (8.44), creating in the process an imaginary universe where the sons of light and the sons of darkness are much more clearly distinct from each other than they may ever have been in real life. It is wise to take John's dualism and the accompanying stereotyped characterization as a product of an effort to construct a clearly defined social identity rather than as a direct reflection of the real world.

Contacts with the members of stereotyped outgroups may sometimes reduce tension and conflicts between groups, but, unfortunately, many social psychological studies have shown that this is not always the case. As Henri Tajfel has remarked:

There is good evidence that even when facts do turn against us and destroy the useful and comfortable distinctions, we still find ways to preserve the general content of our categories... In many social situations which present notorious ambiguities of interpretation, it will always be easier to find supporting evidence for the assumed class characteristics of an individual than to find contradictory evidence. ${ }^{57}$

Groups have various ways of dealing with information that disconfirms their stereotyped view of reality. One such way is called subtyping. This term refers

portrayals of Jews are dominant. Setzer asks whether the trend to depict Jews in more positive terms 'is not underrepresented in ancient literature'. The favorable mentions of Jews would not have served early Christian communities because 'if Jews are sensible and fair-minded, their refusal of Christianity becomes more problematic than if they are hard-hearted, vicious, and ignorant of their own Scripture'.

56 See Raimo Hakola, 'The Johannine Community as Jewish Christians? Some Problems in Current Scholarly Consensus', Jewish Christianity Reconsidered: Rethinking Ancient Groups and Texts (ed. M. Jackson-McCabe; Minneapolis: Fortress, 2007) 181-201, esp. 192-7. Many scholars have found in John 8.30-31 a reference to some kind of Jewish Christians whose faith is denounced by John. Most recently M. Theobald, 'Abraham-(Isaak-) Jakob: Israels Väter im Johannesevangelium', Israel und seine Heilstraditionen im Johannesevangelium: Festgabe für Johannes Beutler SJ zum 7o. Geburtstag (ed. M. Labahn, K. Scholtissek and A. Strotmann; Paderborn: Ferdinand Schöningh, 2004) 158-83, esp. 175-7; I. Dunderberg, The Beloved Disciple in Conflict? Revisiting the Gospels of John and Thomas (Oxford: Oxford University, 2006) 194.

57 Tajfel, Human Groups, 132-3. 
to a process of recategorizing an individual not fitting to a persistent stereotype into a new lower-level social category. This new subtype makes the original stereotype more flexible and permits groups to sustain prejudiced beliefs even when they confront contradictory evidence. This process is well described by Ziva Kunda and Kathryn Oleson:

Positive contacts may fail to affect stereotypes because people do not generalize from the positive members whom they have encountered to the groups as a whole. Rather, when people encounter group members who violate a group stereotype...they 'fence off' these members by assuming that they constitute a distinct subtype of the group. Consigning deviants to a subtype believed to be atypical and unrepresentative of the group as a whole may enable people to maintain their pre-existing global stereotypes even though they are aware that deviants exist. ${ }^{58}$

Subtyping can be seen as a way to protect a stereotype from change. As a matter of fact, this cognitive process may even strengthen the original stereotype by making it more adaptable to changing social contexts that always have a potential to challenge the accuracy of fixed and monochrome categories. This is detailed by Miles Hewstone and his colleagues:

Increased awareness that a target group is heterogeneous is not necessarily a harbinger of stereotype change. In fact, somewhat paradoxically, it may make change more difficult to achieve... By increasing the variability of a stereotype when inconsistent group members are encountered, social perceivers can maintain the stereotype's central tendency. ${ }^{59}$

I propose that Nicodemus may have functioned as this kind of deviant subtype for the Johannine Christians. As a Jew and a Pharisee whose faith is not quite enough despite his positive response to Jesus, Nicodemus may have allowed the Johannine group to come to terms with Jewish groups and individuals whose response to early Christians and Jesus was, at least to some extent, positive. Jews of this kind would not have a proper place in the two-dimensional symbolic world of the Johannine Christians but Nicodemus as an ambiguous textual character made it possible for the Johannine group to hold fast to the basic dichotomy in their symbolic world.

58 Z. Kunda and K. Oleson, 'Maintaining Stereotypes in the Face of Disconfirmation: Constructing Grounds for Subtyping Deviants', Journal of Personality and Social Psychology 68 (1995) 565-79, esp. 565.

59 M. C. Hewstone, 'Cognitive Models of Stereotype Change: (5). Measurement, Development and Consequences of Subtyping', Journal of Experimental Social Psychology 30 (1994) 505-26, esp. 523. 


\section{Conclusions}

In this article, I have complemented a purely text-centered approach, which takes Nicodemus as an ambiguous literary character, and asked how this literary character may have functioned as a symbol for those who shared John's dualistic tendencies. I have examined what role Nicodemus may have played in the construction and maintenance of a distinct early Christian identity. The social identity approach makes it possible to take seriously both the severe criticism of Nicodemus in John 3 and his more positive appearances in John 7 and 19. While a purely text-centered approach goes only halfway toward explaining John's seemingly conflicting images of Nicodemus, the wider perspective adopted here explains how both negative and positive appraisals of Nicodemus may have contributed to early Christian identity. While differing portraits may clash in the text world, they may well have a parallel function as different components of the symbolic world that validates the social identity of the writer and his audience.

Jesus' harsh words to Nicodemus in John 3 suggest that, for John and his readers, Nicodemus is not simply a literary construct with recognizable individual features but a symbol of groups that had a crucial function for how they understood their position in the world. As a Pharisee and a Jew, Nicodemus represents an unbelieving and even hostile world that cannot accept Jesus. This initial critical stance towards Nicodemus is not necessarily contrary to a qualified approval of this character later in the Gospel. Rather, it is especially in his role as an outsider that Nicodemus can give a boost to the social identity of the Johannine group. The mere presence of a Pharisee who does not consistently sustain the rejection of Jesus and his message serves to contest the principles the Pharisees represent in the Gospel. Finally, as an ambiguous literary character, Nicodemus may have helped John and his audience to accept the ambiguities and uncertainties in their social environment without abandoning the basic thrust of their symbolic world. Despite the realistic evidence to the contrary, they could have continued to count the Pharisees and other Jews as the ones who are single-minded and undivided in their intense struggle against Jesus and his followers. Given the persistence of two-dimensional and extreme tendencies in how individuals and groups define themselves in relation to others, the appearance of such an ambiguous literary character as Nicodemus may not be enough to counter the dualistic polarities evident in the rest of the Gospel-even though such polarities hardly ever provide a fair picture of the complexities of real life. ${ }^{60}$

60 Cf. Hakola, 'The Counsel of Caiaphas', 159. 